\title{
Influence of Guided Inquiry Learning Model and Social Interactions on PPKn Lesson Result of 5th Grade Students in Primary School (SDN) 040444 Kabanjahe School Year 2017/2018
}

\author{
Monica Agita Br Tarigan', Reh Bungana Br Perangin-Angin ${ }^{2}$, Daulat Saragi ${ }^{3}$ \\ ${ }^{1}$ Master Student in State University of Medan (Unimed), Indonesia \\ ${ }^{2}$ Lecturer in State University of Medan (Unimed), Indonesia \\ monictrg@gmail.com
}

\begin{abstract}
The purpose of this study was to find out: the PPKn learning outcomes of students taught with guided inquiry learning models, PPKn learning outcomes of students who had cooperative social interactions were higher than the learning outcomes of PPKn students who had competitive social interaction; and the interaction between guided inquiry learning models and social interactions on learning outcomes. This research is a quasi-experimental study. The population in this study were all V grade students in Primary School 040444 of Kabanjahe, while the sample in this study were 35 students of $V$-A class and 35 students of V-B class. The instrument consists of learning outcomes tests in the form of multiple choice tests and social interaction questionnaires. Data analysis using anawa two paths with the help of IBM SPSS Statistics 25 and Excel 2013 applications. The results showed that: PPKn learning outcomes of students taught using a guided inquiry learning model amounted to 82.79 higher than the average PPKn learning outcomes using the model. expository learning is 66.98, learning outcomes of students who have cooperative social interactions have an average of 87.46 and student learning outcomes that have a competitive social interaction averaging 85.3, and there are social interactions between guided inquiry learning models and interactions social influence on student learning outcomes.
\end{abstract}

Keywords : learning model; guided inquiry; social interaction; results study PPKn

\section{Introduction}

The progress of science and technology is increasingly rapid resulting in easy people to access information and communication that have a positive and negative impact on community life. The positive impact of the progress is to open the opportunity for the realization of interaction for everyone, while the negative impact is the decline in values and norms in society.

The decline in values and norms in society has resulted in various conflicts that occur, especially in the world of education that affect teaching and learning activities (KBM). Such as the occurrence of conflict between students and teachers, where students lack respect for the advice given by their teacher. There are also teachers who lack empathy for the problems experienced by students.

Various conflict phenomena that occur are caused by the use of time that is not maximal in KBM. Likewise with students who are less active in the learning process. Where students are not given the opportunity to express their thoughts in teaching and learning activities, thus making students apathetic like only doing $3 \mathrm{DCH}$, which is sitting, silent, listening, noting, and memorizing.

Learning activities in schools are the main activities in improving the quality of national education. Through the teaching and learning process it is expected to achieve educational goals in the form of changes in students' behavior. This learning process requires language to enable people to interact and communicate with each other, share experiences, learn from others, and improve their intellectuality (Anzar \& Mardhatillah, 2018) 
Learning is a modification or strengthening behavior through experience. According to him, this experience can be obtained from the interaction between individuals and their environment (Wirdaningsih \& Mardhatillah, 2016)

In the teaching and learning process must be able to create a learning atmosphere that makes students enjoy and want to follow seriously the lessons delivered by the teacher, so that students are interested in following the learning process that takes place. In other words, the interaction that is established must be able to create an active and participatory and productive learning atmosphere so that students can achieve the learning objectives that have been set.

The fact is that the current teaching and learning process that takes place in schools, there are still various problems in the delivery of material, making students apathetic or lacking enthusiasm in participating in the learning process. Many students are daydreaming and sleepy, and some even bother their friends who are studying.

From the results of interviews with the homeroom $\mathrm{V}$ grade students of primary school 040444 Kabanjahe. One of the fundamental problems in PPKn subjects is that the participation of students in KBM is still low. This was evident when the PPKn subjects took place, many students did not pay attention to the teacher who was delivering the material in front of the class. Likewise in the implementation of teaching and learning activities teachers rarely give assignments in groups to students which results in a lack of cooperation between students during teaching and learning activities, and more often provide independent assignments, so that social interactions that occur in the classroom do not take place effectively because students compete more often and there are also student learning outcomes that are still under the KKM.

The learning outcomes of PPKn subjects have not been maximally influenced by various factors, both internal and external factors. One of the external factors that is very influential is the use of the learning model used by the teacher in delivering the material not yet on target especially in the PPKn subjects.

Teaching and learning activities that take place are also more often carried out expository learning models and rarely use learning models that are activating students in KBM for example using a guided inquiry learning model. In this expository learning model the teacher uses more lecturing methods because the learning process is centered on the teacher, while the students only pay attention and take notes for those who feel the need.

The expository learning model is a learning model that is focus on teacher activities, while students are passive. The use of the expository model can continuously foster a verbalistic culture that causes students to memorize only the PPKn subjects. This is because verbalistic culture emphasizes knowledge skills (C1) and understanding (C2) only, not in accordance with 2013 Curriculum (K13). This learning model will make students smart, but less able to apply it to everyday life. Students become afraid to express their opinions, do not dare to try to cause learning to be passive.

The process of teaching and learning activities needs to create a class atmosphere to be active. Facing students to tasks that can improve knowledge, attitudes, and skills in accordance with K13. According to Sabri (2010: 19) that learning is a change in behavior, which includes intellectual aspects, attitudes, and skills acquired after through the activities of the senses namely seeing, hearing, smelling, and touching or obtained thanks to experience and training. Likewise, familiarizing students with tasks independently, so that they compete to get an award from the teacher. In addition, learning also needs to direct students to be able to do tasks by collaborating in groups to improve social skills, a sense of solidarity, sympathy and empathy for others. Thus learning will be oriented to independence and cooperation, these conditions 
will familiarize learners to compete with sportsmanship and on the other hand students will feel the need for help from other friends.

To improve student learning outcomes and overcome interactions between teachers and V grade students of Primary school 040444 Kabanjahe, see the school background so that the model is appropriate. From the observations made by this school, many people are interested, as seen from the number of students, especially $\mathrm{V}$ grade, there are two classes, namely $\mathrm{V}-\mathrm{A}$ and V-B grade. This school is also located in the middle of Kabanjahe City and has accredited B. Therefore, a guided inquiry model and cooperative and competitive social interaction are applied. Because this guided inquiry learning model and social interaction are considered suitable with the background of the Primary school 040444 Kabanjahe.

The guided model of inquiry learning is a set of delivery of teaching materials by making learners active in searching, finding, and drawing conclusions with directions provided by teachers. So also creates an atmosphere of learning that can increase students' attractiveness by means of competitive social interaction and cooperative social interaction.

Based on the above problems it is known that the importance of guided inquiry learning models and social interactions in the implementation of teaching learning activities in particular the subjects of the CCP. Therefore it will be implemented KBM improvements entitled: "Influence of Guided Inquiry Learning Model and Social Interactions on PPKn Lesson Result of 5th Grade Students in Primary School (SDN) 040444 Kabanjahe School Year 2017/2018”.

\section{Review of Literature}

\subsection{Guided Inquiry Learning Model}

According to Fathurrohman (2015: 104) in his book entitled Innovative Learning Models that the inquiry learning model (inquiry), is one of the well-known learning models. Inquiry comes from the word to inquire which means participating or being involved in asking questions, asking for information, looking for information or sources, and investigating a problem. The purpose of the inquiry learning model is to provide ways for students to improve intellectual skills associated with reflective thinking processes.

Furthermore, according to Aqib and Murtadlo (2016: 261) in his book entitled Collection of Creative and Innovative Learning Methods that guided discovery learning is one part of discovery learning that involves many students, so active and participatory in teaching and learning activities. Judging from the interaction activities between educators and students and also between students and other students, it can be said that guided discovery is a combination of direct learning and indirect learning.

From the above definition it can be stated that the guided inquiry learning model is a series of activities that direct students to think critically by finding and finding information to be able to solve problems given by educators by conducting observations or experiments, and aiming to improve intellectual, emotional, and skills of students. The usual critical thinking process is done through question and answer from reading or drawing between teacher and students

\subsection{Social Interaction}


Interaction refers to the term communication or relationship that takes place between individuals, individuals with groups, and groups with groups. Communication or relationships that occur are usually caused by wanting to convey a message (message), while social is a relationship between every human being.

According to Susanto $(2011: 137)$ that social interaction is an activity that is related to other people or other parties who need socialization in terms of behaving to be accepted by others, so also practice using characters that can be recognized by others, and trying to develop social attitudes which is recognized by others. It can be said that social interaction is a reciprocal relationship between individuals, between individuals and groups, and between groups with groups that influence each other. Furthermore, according to Santoso (2010: 164) that social interaction is a relationship between two individuals or more, where one individual's actions influence, can change or improve the behavior of another individual or vice versa. It can be seen that the interactions that students have are very important to be developed for the better, because they influence each other among students.

It can be concluded that social interaction is a relationship between one individual to another, individual one can influence other individuals or vice versa. That way in social interaction there is a reciprocal relationship between individuals and individuals, individuals with groups, and groups with groups that influence each other that can change or improve one another.

\subsection{Result of PPKn Learning}

Learning outcomes are changes that include the personal aspects of students who are acquired after following the learning process. This idea is in accordance with Sudjana's opinion (2013: 3) "learning outcomes are behavioral changes that include the fields of cognitive, affective, and psychomotor owned by students after receiving learning experiences".

PPKn subjects always relate to human behavior and actions in community life, to understand their rights and obligations as citizens. The subjects of PPKn also equip students with the knowledge to love the State of Indonesia, so that they are willing and able to defend Indonesia. In accordance with article 39 of Law No. 20 of 2003 concerning the National Education System which confirms that PPKn is a process of preparing students with knowledge and skills related to citizens with the state and the history of Indonesia relating to educational heroes who defend the country, so that students become citizens who can be relied on by the nation and state.

According to Azra (2008: 5) the essence of citizenship education is an effort that is carried out consciously and planned to educate the nation's life, together with every citizen foster national identity and morals based on the implementation of rights and obligations in defending the country, and also for the sake of continuity the life and glory of the nation and state. The aim of citizenship education is to make citizens aware of wanting to defend the country based on a national political understanding, and sensitive to develop national identity and morals in the life of the nation.

From a number of expert opinions above, it can be concluded that the PPKn learning outcomes are behavioral changes that affect cognitive, affective and psychomotor abilities caused by the experiences experienced by students after going through the teaching and learning process. Learning outcomes will also affect the behavior of students in living in the midst of family, school and society. 


\section{Research Method}

This research was conducted at Primary school 040444 Kabanjahe located on Jalan Nabung Surbakti 125 / s Yon Complex, Padang Mas Village, Kabanjahe District, Karo Regency. The research is conducted for 4 weeks in the second semester 2018/2019 Academic Year which starts in the second week of May to the first week of June.

The population in this study were all students of Primary School 040444 Kabanjahe which total 70 students that consisting of 2 classes, namely: V-A and V-B grade. V-A grade becomes an experimental class with a guided inquiry learning model and $\mathrm{V}$-B grade becomes a control class with an expository learning model.

In this study there are three variables, namely two independent variables (learning and social interaction models) and dependent variables (learning outcomes). The design of this study uses experimental research methods because this study wants to know certain treatments (ratings) against others (Sugiono, 2009: 34). This study uses a quasi-experimental factorial $2 \mathrm{x}$ 2 design. The research instruments used: 1) HOTS oriented test questions to see the PPKn learning outcomes, and 2) social interaction questionnaires to see students who have cooperative social interactions and students who have competitive social interactions.

\section{Discussion}

\subsection{There Are Differences in Learning Result of PKn Students Use a Guided Inquiry Model with an Expository Model}

The results of the analysis of variance obtained a significance value of the learning model of 0,000 . Because the sig value. $0,000<0,005$, so that the results of hypothesis testing reject $\mathrm{H}_{0}$ or accept $\mathrm{H}_{\mathrm{a}}$ in alpha level 5\%, meaning that there are differences in PPKn learning outcomes of students taught with guided inquiry learning models and expository learning models on PPKn subjects. The results of this hypothesis test can be concluded that students who are taught with guided inquiry learning models obtain an average value of learning outcomes better than students who are taught expository.

\subsection{There Are Differences in Learning Outcomes PKn Students Have Cooperative Social Interactions with Students who have Competitive Social Interactions}

The results of the analysis of variance obtained a significance value of the learning model of 0,000 . Because the sig value. $0,000<0,005$, so that the results of hypothesis testing reject $\mathrm{H}_{0}$ or accept $\mathrm{H}_{\mathrm{a}}$ in the alpha level 5\%, meaning that there are differences in PPKn learning outcomes of students who have cooperative social interactions and competitive social interactions on PPKn subjects. The results of this hypothesis test can be concluded that the PPKn learning outcomes of groups of students have higher cooperative social interactions than groups of students have competitive social interactions.

\subsection{There are Interactions between Learning Models and Social Interactions in Influencing Student PPKn Learning Outcomes}

The results of the analysis of variance, obtained a significance value of the learning model of 0,000 . Because the sig value. $0,000<0,005$, so that the results of hypothesis testing reject $\mathrm{H}_{0}$ or accept $\mathrm{H}_{\mathrm{a}}$ in the alpha level $5 \%$, meaning there is an interaction between the 
learning model and students' social interactions in influencing student PPKn learning outcomes.

\section{Conclusion}

Based on the results of the analysis of research data, conclusions can be stated as follows:

1. The learning model has an influence on PPKn learning outcomes. Students taught with guided inquiry learning models have higher learning outcomes compared to the expository learning model on PPKn subjects material Obligations, Rights, and Responsibilities as Citizens in the V grade of Primary School 040444 Kabanjahe. This is evidenced through calculations that show a significant difference between students taught with a guided inquiry learning model of 82.79 with an expository learning model of 66.98 .

2. Social interaction has an influence on PPKn learning outcomes. Students who have cooperative social interactions get better learning outcomes than students who have competitive social interactions in V grade Primary school 040444 Kabanjahe. This is evidenced through calculations that show differences in PPKn learning outcomes of students who have cooperative social interactions 87.46 with students who have competitive social interactions 75.3.

3. There is an interaction between the learning model and social interaction in influencing the PPKn learning outcomes of students in V grade Primary school 04044 Kabanjahe. This social interaction has more role for students with cooperative social interactions taught with guided inquiry learning models compared to competitive social interactions that are taught using expository learning models.

\section{References}

Anzar, S. F., \& Mardhatillah, M. (2018). Analisis Kesulitan Belajar Siswa Pada Pembelajaran Bahasa Indonesia di Kelas V SD Negeri 20 Meulaboh Kabupaten Aceh Barat Tahun Ajaran 2015/2016. Bina Gogik, 4(1).

Aqib, Zainal. (2006). Penelitian Tindakan Kelas. Bandung : Yrama Widya.

Aqib, Zainal. (2010). Penelitian Tindakan Kelas. Bandung: Yrama Widya.

Arikunto, Suhasimi. (2012). Prosedur Penelitian Suatu Pendekatan Praktik. Jakarta: Rineka Cipta.

Daryanto. (2010). Belajar dan Mengajar. Bandung: CV Yrama Widya.

Dimyati \& Mudhiono. (2013). Belajar dan Pembelajaran. Jakarta: Rineka Cipta.

Djamarah, Syaiful Bahri \& Asman Zain. (2012). Strategi Belajar Mengajar. Jakarta: Rineka Cipta.

Ekawarna. (2011). Penelitian Tindakan Kelas. Jakarta: Gaung Persada Tukiran

Fathurrohman, Pupuh \& Sabry Sutikno. (2007). Strategi Belajar Mengajar. Bandung: Refika Aditama.

Gatara, Asep Sahid dan Subhan Sofhian. 2011. Pendidikan Kewarganegaraan (Civic Education ). Bandung : Fokusmedia.

Hamalik. Oemar. (2011). Proses Belajar Mengajar. Jakarta: Bumi Aksara.

Hamdani. (2011). Strategi Belajar Mengajar. Bandung: Pustaka Setia.

Iif Khoiru Ahmadi, dkk. (2011) Sekolah Terpadu - Model Pembelajaran. Jakarta: Prestasi Pustaka. 
Istarani. (2012). 58 Model Pembelajaran Inovatif. Medan: Media Persada.

Jihad, Asep \& Abdul Haris. (2013). Evaluasi Pembelajaran. Yogyakarta: Muti Pressindo.

Mardhatillah, M., \& Trisdania, E. (2018). Pengembangan Media Pembelajaran Berbasis Macromedia Flash Untuk Meningkatkan Kemampuan Membaca Siswa di SD Kelas II Negeri Paya Peunaga Kecamatan Meureubo. Bina Gogik, 5(1).

Purwanto. (2011). Evaluasi Hasil Belajar. Yogyakarta: Pustaka Pelajar.

Sabri, Ahmad. (2010). Strategi Belajar Mengajar. Jakarta: Quantum Teaching.

Sagala, Syaiful. (2007). Konsep dan Makna Pembelajaran. Bandung: CV Alfabeta.

Sahartian, Piet A. (2010). Supervisi Pendidikan. Jakarta: Rineka Cipta.

Sanjaya, Wina. (2010). Penelitian Tindakan Kelas. Jakarta: Perdana Media Group.

Siregar, Eveline \& Hartini Nara. (2010). Teori Belajar dan Pembelajaran. Bogor: Ghalia Indonesia.

Slameto. (2010). Belajar \& Faktor-Faktor yang Mempengaruhi. Jakarta: Rineka Cipta.

Sudjana, Nana. (2013). Penilaian Hasil Proses Belajar Mengajar. Bandung: PT Remaja Rosdakarya.

Suryanto, Adi. (2009). Evaluasi Pendidikan di SD. Jakarta: Universitas Terbuka.

Taniredja, et al. (2012). Model-Model Pembelajaran Inovatif dan Efektif. Bandung: Alfabeta.

Trianto. (2011). Mendesain Model Pembelajaran Inovaso - Progresif. Jakarta: Kencana.

Wirdaningsih, W., \& Mardhatillah, M. (2016). Penerapan Media Audio-Visual Terhadap Keaktifan Pada Materi Hubungan Antara Sumber Daya Alam Dengan Lingkungan Siswa Kelas IV SD Negeri Pasi Teungoh Kecamatan Kaway XVI. Bina Gogik, 3(2). 